\title{
Effect of Phosphorus Fertilization on Growth and Flowering of Scaevola aemula R. Br. 'New Wonder'
}

\author{
Donglin Zhang, ${ }^{1}$ Renae E. Moran, and Lois B. Stack \\ Department of Plant, Soil and Environmental Sciences, University of Maine, \\ 5722 Deering Hall, Orono, Maine 04469-5722
}

Additional index words. copper, iron, 'New Wonder' fanflower, nutrition, toxicity, zinc

Abstract. Scaevola aemula R.Br. (fanflower), an ornamental plant native to Australia, produces stunted growth when fertilized with high concentrations of $P$. To determine optimum $P$ concentration, rooted cuttings were transplanted into $15 \mathrm{~cm}$ standard pots and grown with a water soluble fertilizer, where $P$ concentrations were $0,14.5,29.0,43.5,58.0,72.5$, $87.0 \mathrm{mg} \cdot \mathrm{L}^{-1}$ and all plants received $200 \mathrm{mg} \cdot \mathrm{L}^{-1} \mathrm{~N}$ and $166 \mathrm{mg} \cdot \mathrm{L}^{-1} \mathrm{~K}$. Shoot growth and flowering data were taken every 21 days until the experiment was terminated after 84 days. Shoot length, number and dry weight, and leaf size were reduced significantly at $P$ concentrations higher than $14.5 \mathrm{mg} \cdot \mathrm{L}^{-1}$ with severe reduction at $P$ levels higher than 43.5 $\mathrm{mg} \cdot \mathrm{L}^{-1}$. Number of flowers per plant was not affected by $\mathbf{P}$ concentrations in the range of 0 to $43.5 \mathrm{mg} \cdot \mathrm{L}^{-1}$, but decreased significantly at $P$ levels higher than $43.5 \mathrm{mg} \cdot \mathrm{L}^{-1}$. Medium $\mathbf{p H}$ decreased with increase in $\mathbf{P}$ rate due to the acidic nature of the $\mathbf{P}$ fertilizer. When $P$ was applied in every irrigation, the optimum concentration was $14.5 \mathrm{mg} \cdot \mathrm{L}^{-1}$ or less. $P$ greater than $43.5 \mathrm{mg} \cdot \mathrm{L}^{-1}$ was detrimental to vegetative growth and flowering, possibly due to above optimum $P$ or to medium acidification.

Scaevola aemula R. Br., a member of Goodeniaceae, is commonly called fanflower because each flower's five petals are at one side, like a fan. 'New Wonder' is a Proven Winner cultivar, widely used for hanging baskets and as a bedding plant (Armitage, 1997; Starman and Faust, 1996) making it an economically important plant. Because it is grown for its long shoots and profusion of flowers, factors that adversely affect these reduce its visual appeal and limit its value as an ornamental.

Recently, the authors, as well as commercial growers in the northern U.S., observed reduced growth and flowering when this plant was fertilized with $\mathrm{P}$ in the early production stage. Poor performance has a potentially large negative influence on new plants, whose growth requirements, including nutrient regime, is not well documented. Since its native soil in Australia is a sandy mix with low $\mathrm{P}$, it is possible that $\mathrm{P}$ concentrations currently used to fertilize this plant may be too high. Symptoms of P toxicity are stunting of shoot growth and dieback of older leaves (Foote and Howell, 1964; Warren and Benzian, 1959). Hordeum vulgare Barley (Richards and Rees, 1962), Lupinus luteus Lupin (Warren and Benzian, 1959),

Received for publication 9 Sept. 2003. Accepted for publication $23 \mathrm{Feb}$. 2004. Maine Agricultural and Forestry Experiment Station publication 2738. Financial support from Maine Agricultural Center grant and Maine R\&D funds made this project possible. We thank Pleasant View Gardens (Loudon, N.H.) for its contribution of plant materials and Douglas Cox and Leonard Perry for reviewing this paper. Suggestions and help from Rob Farquhar, Bruce Hoskins, Bradley Libby, Rebecca Morgan, Stacy Ruchala, and Richard Seekins are appreciated.

${ }^{1}$ To whom reprint requests should be addressed; e-maildonglin@maine.edu.
Euphorbia pulcherrima poinsettia (Whipker and Hammer, 1994) and some cultivars of Glycine max soybean (Foote and Howell, 1964) are reported to be sensitive to high $P$, but this problem has not yet been documented for scaevola. Our objective was to determine the optimum concentration of $\mathrm{P}$ fertilizer for growth and flowering of Scaevola aemula 'New Wonder'.

\section{Materials and Methods}

Rooted cuttings were transplanted into 1.7-L $(15-\mathrm{cm})$ standard, round plastic pots (Dillen Products Inc., Middlefield, Ohio) with Premier Pro-Mix BX (Red Hill, Pa.) on 30 Mar. 2001. Plants did not receive fertilizer until the start of the treatments. All plants were grown in a heated glass greenhouse in Orono, Maine. Day temperature ranged from 20 to $24{ }^{\circ} \mathrm{C}$ and night temperature from 18 to 21 ${ }^{\circ} \mathrm{C}$. Plants received natural light. When plants were well-established on 6 Apr. 2001, the P treatments began.

Treatments included seven levels of $\mathrm{P}$, which were $0,14.5,29.0,43.5,58.0,72.5$, and $87.0 \mathrm{mg} \cdot \mathrm{L}^{-1}$ (actual $\left.\mathrm{P}\right)$. All treatments received $200 \mathrm{mg} \cdot \mathrm{L}^{-1} \mathrm{~N}$ and $166 \mathrm{mg} \cdot \mathrm{L}^{-1} \mathrm{~K}$ except for an additional control, which received only water. Plants were fertilized whenever the medium surface appeared dry (usually two to three times per week). To avoid salt accumulation, tap water alone was applied after every three fertigations. Tap water $\mathrm{pH}$ was 8.5 , electric conductivity was $202 \mu \mathrm{mhos} \cdot \mathrm{cm}^{-1}$, and alkalinity was $59 \mathrm{mg} \cdot \mathrm{L}^{-1}$. The tap water contained the following levels of nutrients: $0.10 \mathrm{mg} \cdot \mathrm{L}^{-1} \mathrm{NO}_{3}$, $0.35 \mathrm{mg} \cdot \mathrm{L}^{-1} \mathrm{P}, 24 \mathrm{mg} \cdot \mathrm{L}^{-1} \mathrm{~K}, 10.7 \mathrm{mg} \cdot \mathrm{L}^{-1} \mathrm{Ca}$, $2.2 \mathrm{mg} \cdot \mathrm{L}^{-1} \mathrm{Mg},<0.01 \mathrm{mg} \cdot \mathrm{L}^{-1} \mathrm{~B},<0.01 \mathrm{mg} \cdot \mathrm{L}^{-1}$ $\mathrm{Zn}, 0.03 \mathrm{mg} \cdot \mathrm{L}^{-1} \mathrm{Mn}, 0.24 \mathrm{mg} \cdot \mathrm{L}^{-1} \mathrm{Fe}$ and 0.145 $\mathrm{mg} \cdot \mathrm{L}^{-1} \mathrm{Cu}$. The Scotts Company (Marysville, Ohio) Peters water soluble fertilizer 20N-8.7P-
16.6K (General Purpose) and 20N-0P-16.6K (Hi-Cal Peat-Lite) were used to prepare the different fertilizer concentrations. These two fertilizers were chosen because they contained the same concentration of $\mathrm{N}$ and $\mathrm{K}$, but differed in concentration of $\mathrm{P}$. They were used alone or in combination to get the desired rate of $\mathrm{P}$. The $\mathrm{P}$-free fertilizer had a potential basicity equivalent to $10 \mathrm{~g} \cdot \mathrm{kg}^{-1} \mathrm{CaCO}_{3}$, and the $\mathrm{P}$-containing fertilizer had a potential acidity equivalent to $279 \mathrm{~g} \cdot \mathrm{kg}^{-1} \mathrm{CaCO}_{3}$.

Shoot growth and flowering data were taken 27 Apr., 18 May, 8 June, and 29 June 2001. Data included length of the longest shoot on each plant, number of nodes on the longest shoot, number of shoots longer than $10 \mathrm{~cm}$, and number of flowers. Shoot dry weight was measured on four plants from each treatment at each date. At the termination of the experiment on 29 June, a subsample of leaves was collected for measurement of leaf size with a portable leaf area meter (LI-3000A, LI-COR, Lincoln, Neb.).

Growing medium samples were collected every $21 \mathrm{~d}$ and analyzed by the University of Maine Analytical Lab (Orono, Maine) for $\mathrm{pH}$, soluble salts, N, P, K, Ca, Mg, B, Cu, Fe, Zn and $\mathrm{Mn}$. Nutrients were measured using the saturated media extract method (Warncke, 1995) and by inductively coupled plasma emission spectroscopy, $\mathrm{NO}_{3}$ and $\mathrm{NH}_{4}$ colorimetrically, and soluble salts by electrical conductivity. A completely randomized block design was employed with a total of 192 potted plants randomly placed in one of four blocks. Each treatment was replicated four times and had six plants per replication. Data were analyzed using analysis of variance to test for the linear and quadratic effect of $\mathrm{P}$. The unfertilized control was not included in the trend analysis. Mean separation was performed on all treatments using Tukey's studentized range (HSD) test (SPSS Inc., 2003).

\section{Results and Discussion}

Phosphorus had a significant influence on shoot growth of 'New Wonder' fanflower. Length of the longest shoot was initially about $20 \mathrm{~cm}$, and this increased 3 -fold over the course of the experiment (Fig. 1a). At 21, 42 , and $84 \mathrm{~d}$, length of the longest shoot was reduced by $\mathrm{P}$ above $14.5 \mathrm{mg} \cdot \mathrm{L}^{-1}$. At $63 \mathrm{~d}$, there was no difference at concentrations lower than $14.5 \mathrm{mg} \cdot \mathrm{L}^{-1}$, but a reduction by $\mathrm{P}$ above this concentration. The number of shoots per plant was initially low with an average of less than 10 at the first measurement date and more than five times as many by the final date (Fig. $1 \mathrm{~b})$. There was a reduction in the number of shoots per plant by the higher concentrations of $\mathrm{P}$ at all measurement dates. In this experiment, a shoot was defined as having a length greater than $10 \mathrm{~cm}$. At 42 and $63 \mathrm{~d}$, there was a reduction in number of shoots, but only when $\mathrm{P}$ was higher than $43.5 \mathrm{mg} \cdot \mathrm{L}^{-1}$. Shoot dry weight also increased steadily throughout the course of the experiment, but this increase was not as great in plants receiving high rates of P (Fig. 1c). At 21 and 63 d, shoot dry weight decreased as the rate of $\mathrm{P}$ increased, especially 
after plants were in production for $42 \mathrm{~d}$ or more. At 42 and 84 d, there was little or no response to $\mathrm{P}$ at concentrations of 0 and 14.5 $\mathrm{mg} \cdot \mathrm{L}^{-1}$, but above this, a reduction occurred with increase in $P$.

Leaf size, number of nodes, and amount of flowering were affected by P levels. After $84 \mathrm{~d}$ of fertilization, plants that received only water had the smallest leaves (Table 1). The water only control also had the least number of nodes per shoot and number of flowers per plant. These plants were stunted and produced few flowers indicating a need for $\mathrm{N}$ and $\mathrm{K}$ for optimum growth. Leaf size was reduced by $\mathrm{P}$ in the range of 14.5 to $87 \mathrm{mg} \cdot \mathrm{L}^{-1}$. The number of nodes on the longest shoot decreased as the rate of the $\mathrm{P}$ increased. The largest number of nodes occurred in the $14.5 \mathrm{mg} \cdot \mathrm{L}^{-1} \mathrm{P}$ treatment, while the least number was observed in the $87 \mathrm{mg} \cdot \mathrm{L}^{-1} \mathrm{P}$ treatment (Table 1). Based on the reduction in number of nodes with no difference in internode length (Fig. 1a), it appears that higher $P$ rates reduced the growth of Scaevola aemula 'New Wonder' by regulating cell development, rather than by regulating cell expansion, as occurs with growth regulators, such as uniconazole, where there is a reduction in internode length with no effect on node number (Starman and Williams, 2000). Because there is only one axillary flower per node, the number of flowers per plant followed the same trend as the number of nodes, decreasing as $\mathrm{P}$ concentration increased. There was a little or no response to $\mathrm{P}$ levels in the range of 0 to $43.5 \mathrm{mg} \cdot \mathrm{L}^{-1}$, but a significant reduction above $43.5 \mathrm{mg} \cdot \mathrm{L}^{-1}$ (Table 1 ). The effect on flowering was apparent from the early flowering stage at $21 \mathrm{~d}$ (data not shown) up to the end of the experiment at $84 \mathrm{~d}$. In contrast to scaevola, lack of $P$ fertilizer reduced vegetative growth and flowering of chrysanthemum (Hansen and Lynch, 1998), petunia and begonia (Baas et al., 1995; James and van Iersel, 2001). Phosphorus in the medium may have been sufficient for early growth of scaevola since there was no significant reduction in growth or flowering in plants receiving $0 \mathrm{mg} \cdot \mathrm{L}^{-1}$. At the start of the experiment $\mathrm{P}$ concentration in the medium was $36 \mathrm{mg} \cdot \mathrm{L}^{-1}$. This decreased to $5 \mathrm{mg} \cdot \mathrm{L}^{-1}$ by $21 \mathrm{~d}$ in the $0 \mathrm{mg} \cdot \mathrm{L}^{-1}$ rate, but was $52 \mathrm{mg} \cdot \mathrm{L}^{-1}$ at the high rate.

The available $\mathrm{P}$ in the medium increased with increase in $\mathrm{P}$ rate at $21 \mathrm{~d}$ of treatment (Fig. 2a). At $\mathrm{P}$ concentrations below 43.5 $\mathrm{mg} \cdot \mathrm{L}^{-1}$, there appeared to be a small effect on medium $\mathrm{P}$, but above $43.5 \mathrm{mg} \cdot \mathrm{L}^{-1}$ there was a larger increase in medium $P$ with increase in $P$ rate. At 42 and $63 \mathrm{~d}$, medium $P$ increased with increase in fertilization rate. At $84 \mathrm{~d}$, increase in medium $\mathrm{P}$ occurred with $\mathrm{P}$ in the range of 0 to $43.5 \mathrm{mg} \cdot \mathrm{L}^{-1}$, and little or no increase at concentrations above $43.5 \mathrm{mg} \cdot \mathrm{L}^{-1}$. Available $\mathrm{N}$ and $\mathrm{K}$ were sufficient under the different $\mathrm{P}$ treatments (data not shown). In the $0 \mathrm{mg} \cdot \mathrm{L}^{-1}$ treatment, medium $\mathrm{pH}$ was above 6.0 after $21 \mathrm{~d}$ and remained near this after $42 \mathrm{~d}$, but decreased to less than 5.5 by $63 \mathrm{~d}$ (Fig. 2b). Medium pH was reduced by increasing $\mathrm{P}$ concentration at 21, 63 and $84 \mathrm{~d}$. Medium $\mathrm{pH}$ was reduced at 42 $\mathrm{d}$ when $\mathrm{P}$ was in the range of 0 to $58 \mathrm{mg} \cdot \mathrm{L}^{-1}$, and no further change in $\mathrm{pH}$ at concentrations above this. At $84 \mathrm{~d}, \mathrm{pH}$ was very acidic for all levels of P. Medium $\mathrm{pH}$ with the highest $\mathrm{P}$ rate reached 4.3 and at the lowest rate reached 5.0. Since $\mathrm{pH}$ below 5.0 can greatly reduce nutrient availability (Lucas and Davis, 1961), it is possible that $\mathrm{P}$ reduced the Scaevola growth and flowering by lowering the availability of nutrients, but this was not measured. A decrease in $\mathrm{pH}$ with increase in $\mathrm{P}$ fertilization occurred in a previous report (James and van Iersel, 2001) and was attributed to the acidity of the Pcontaining fertilizers. This occurred in our study, as well, and may be the reason for the reduction in growth at higher levels of $\mathrm{P}$. Since medium $\mathrm{pH}$ was different between the different treatments, the effect of these two factors on growth cannot be separated. Soluble salts were stable among fertilized treatments with a slight increase with increasing $\mathrm{P}$ levels at 21 and 42 d. At $63 \mathrm{~d}$ there was no effect of $P$ rate on soluble salts, and at $84 \mathrm{~d}$, there was a slight reduction in salts at higher $\mathrm{P}$ concentrations (Fig. 2c).

Micronutrients in the medium, copper, zinc and iron, were affected by $\mathrm{P}$ fertilization. Available copper was initially less than $0.04 \mathrm{mg} \cdot \mathrm{L}^{-1}$. By $63 \mathrm{~d}$, this increased to above $0.06 \mathrm{mg} \cdot \mathrm{L}^{-1}$ with low rates of $\mathrm{P}$, but with the highest rates there was almost no change from the level at 21. As the $\mathrm{P}$ rate increased, available copper in the medium decreased, but only after $21 \mathrm{~d}$ (Fig. 3a). At 42 and $63 d$, there was a reduction in available copper. At $84 \mathrm{~d}$, there was no effect on copper with $\mathrm{P}$ in the range of 0 to 43.5 $\mathrm{mg} \cdot \mathrm{L}^{-1}$, but above this there was a reduction. At $21 \mathrm{~d}$, available iron was below $1 \mathrm{mg} \cdot \mathrm{L}^{-1}$, and was not affected by $\mathrm{P}$ fertilization (Fig. 3b). At $42 \mathrm{~d}$, it was still below $1 \mathrm{mg} \cdot \mathrm{L}^{-1}$, but was reduced by P. At 63 and 84 d, available iron was unchanged or slightly increased by increase in $\mathrm{P}$ in the range of 0 to $43.5 \mathrm{mg} \cdot \mathrm{L}^{-1}$ and decreased at rates above this. Available zinc was reduced by phosphorus at 21 and 42 $\mathrm{d}$, but not significantly affected by $\mathrm{P}$ after 42 d (Fig. 3c). 
Table 1. Effect of phosphorus (P) fertilization rate on number of nodes on the longest shoot, leaf size, and number of flowers of Scaevola aemula 'New Wonder' after $84 \mathrm{~d}$ of fertilization.

\begin{tabular}{cccc}
\hline $\begin{array}{l}\text { P rate } \\
\left(\mathrm{mg} \cdot \mathrm{L}^{-1}\right)\end{array}$ & $\begin{array}{c}\text { Leaf size } \\
\left(\mathrm{cm}^{2}\right)\end{array}$ & $\begin{array}{c}\text { No. of } \\
\text { nodes }\end{array}$ & $\begin{array}{c}\text { No. of } \\
\text { flowers/plant }\end{array}$ \\
\hline Water Only & $3.0 \mathrm{e}^{\mathrm{z}}$ & $29 \mathrm{e}$ & $75 \mathrm{e}$ \\
$0.0^{\mathrm{y}}$ & $5.6 \mathrm{ab}$ & $53 \mathrm{ab}$ & $714 \mathrm{a}$ \\
14.5 & $6.5 \mathrm{a}$ & $58 \mathrm{a}$ & $739 \mathrm{a}$ \\
29.0 & $5.4 \mathrm{~b}$ & $49 \mathrm{bc}$ & $690 \mathrm{ab}$ \\
43.5 & $4.9 \mathrm{bc}$ & $51 \mathrm{abc}$ & $720 \mathrm{a}$ \\
58.0 & $4.1 \mathrm{~cd}$ & $45 \mathrm{~cd}$ & $619 \mathrm{bc}$ \\
72.5 & $3.4 \mathrm{de}$ & $40 \mathrm{~d}$ & $555 \mathrm{~cd}$ \\
87.0 & $3.3 \mathrm{de}$ & $38 \mathrm{~d}$ & $518 \mathrm{~d}$ \\
Prate linear & $* * *$ & $* * *$ & $* * *$ \\
Prate quadratic & NS & NS & $*$ \\
\hline
\end{tabular}

${ }^{2}$ Mean separation within columns by hsd, $P<0.05$.

'The nitrogen and potassium concentrations were 200 and $166 \mathrm{mg} \cdot \mathrm{L}^{-1}$.

${ }^{x}$ Excluding the water only treatment.

NS,,$* * *$ Nonsignificant or significant at $P<0.05$ or 0.001 , respectively.

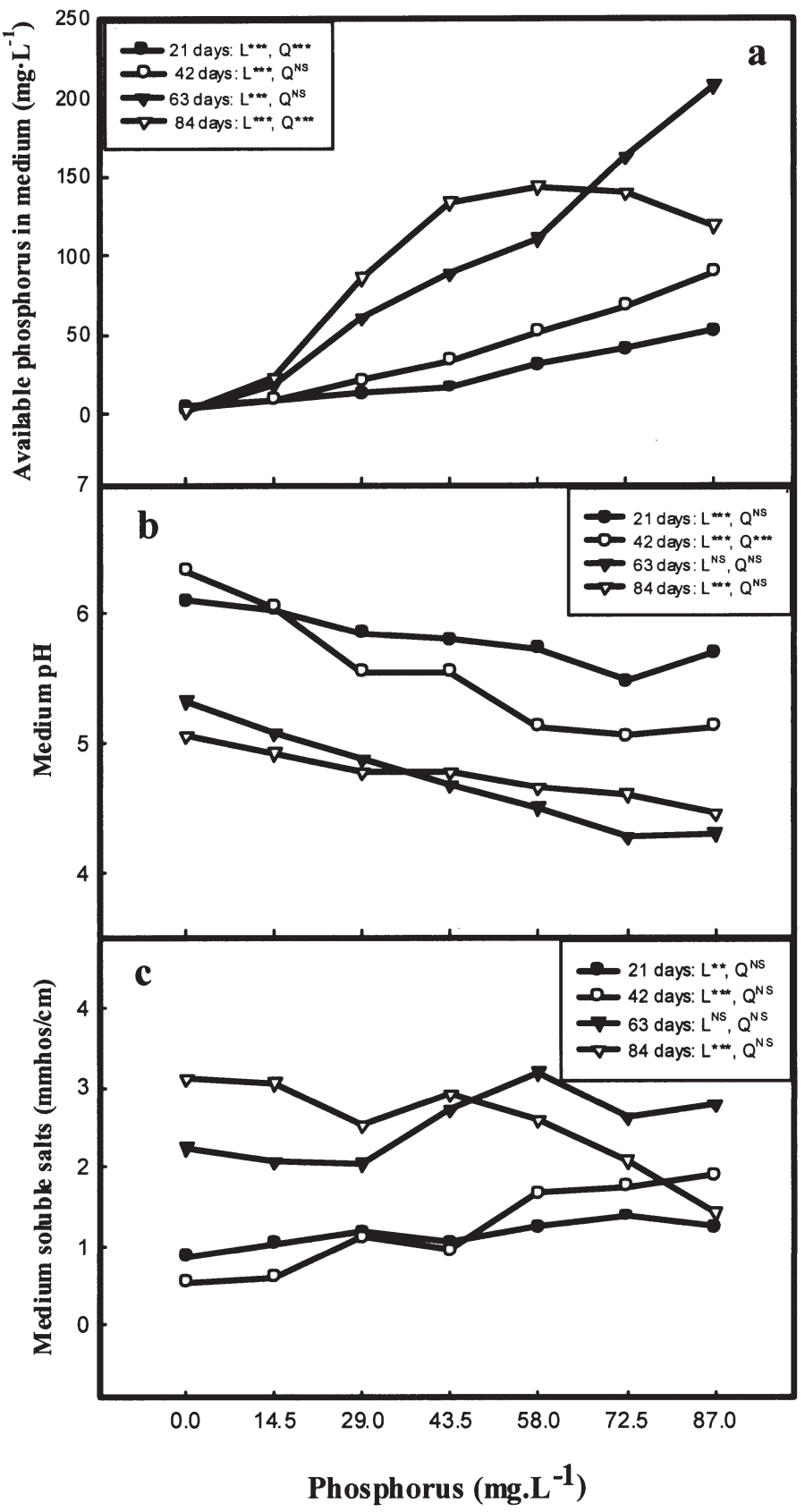

Fig. 2. (a) Medium phosphorus levels, (b) medium pH, and (c) medium soluble salts during $84 \mathrm{~d}$ of phosphorus fertilization of Scaevola aemula 'New Wonder'. $\mathrm{NS}, *, *, * * * *$ Nonsignificant or significant at $P<0.05,0.01$, or 0.001 , respectively.
When concentrations greater than needed lead to a reduction in growth, they are considered toxic, in contrast to luxury consumption, which has no effect (Loneragan and Asher, 1967). Phosphorus toxicity in most species generally occurs when shoot tissue concentration exceeds $0.9 \%$ on a dry weight basis (Loneragan and Asher, 1967). Foliar analysis was not conducted in our study, but should be part of future studies to determine what tissue concentration is associated with toxicity symptoms in Scaevola. Reductions in growth caused by extremely high $\mathrm{P}$ in the medium may be due to phosphate retarding the uptake and translocation of micronutrients such as zinc (Millikan, 1963; Watanabe et al., 1965) iron (Rediske and Biddulph, 1953) or copper (Nus et al., 1993). It is possible that $P$ reduced growth and flowering by reducing the uptake and translocation of these micronutrients, but this was not measured. Phosphorus concentrations above $14.5 \mathrm{mg} \cdot \mathrm{L}^{-1}$ reduced the productivity and economic value of Scaevola aemula 'New Wonder'. This reduction in growth could not be attributed to $\mathrm{P}$ level alone, since medium $\mathrm{pH}$ was reduced by $\mathrm{P}$ fertilization as well.

\section{Literature Cited}

Armitage, A. 1997. Scaevola: A well-traveled plant. Greenhouse Grower 15(4):61-62.

Bass, R., A. Brandts, and N. Straver. 1995. Growth regulation of bedding plants and poinsettia using low phosphorus fertilization and ebb-and-flow irrigation. Acta Hort. 378:129-135.

Foote, B.D. and R.W. Howell. 1964. Phosphorus tolerance and sensitivity of soybeans as related to uptake and translocation. Plant Physiol. 39:610-613.

Hansen, C.W. and J. Lynch. 1998. Response to phosphorus availability during vegetative and reproductive growth of chrysanthemum: II. Biomass and phosphorus dynamics. J. Amer. Soc. Hort. Sci. 123:223-229.

Loneragan, J.F. and C.J. Asher. 1967. Response of plants to phosphate concentration in solution culture. II. Rate of phosphate absorption and its relation to growth. Soil Sci. 103:311-318.

Lucas, R.E. and J.F. Davis. 1961. Relationship between $\mathrm{pH}$ values of organic soils and availabilities of 12 plant nutrients. Soil Sci. 92:177-182.

James, E. and M. van Iersel. 2001. Ebb and flow production of petunias and begonias as affected by fertilizers with different phosphorus content. HortScience 36:282-285.

Millikan, C.R. 1963. Effects of different levels of zinc and phosphorus on the growth of subterranean clover (Trifolium subterraneum). Austral. J. Agr. Res. 14:180-205.

Nus, J.L., N.E. Christians, and K.L. Diesburg. 1993. High phosphorus applications influence soil-available potassium and kentucky bluegrass copper content. 


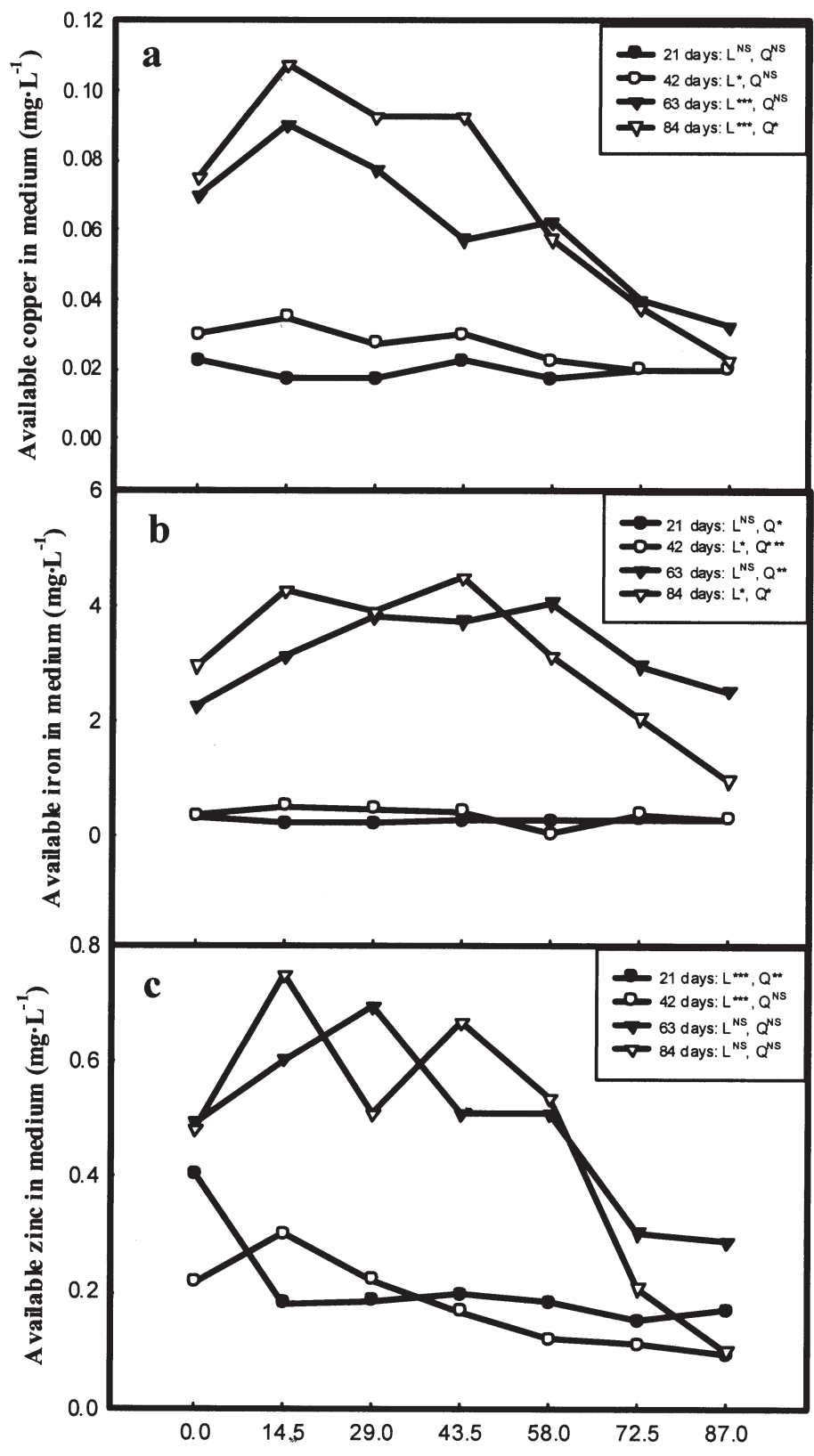

Phosphorus (mg.L $\mathbf{L}^{-1}$ )

Fig. 3. (a) Available copper, (b) iron, and (c) zinc in the medium during $84 \mathrm{~d}$ of phosphorus fertilization of Scaevola aemula 'New Wonder'. NS,*,******Nonsignificant or significant at $P<0.05$, 0.01 , or 0.001 , respectively.

HortScience 28:639-641.

Rediske, J.H. and O. Biddulph. 1953. The absorption and translocation of iron. Plant Physiol. 28:576-593.

Richard, R.J. and A.R. Rees. 1962. Effects of phosphate on the growth of barley under conditions of potassium deficiency. Indian J. Plant Physiol. 5:33-52.

SPSS Inc. 2003. SYSTAT (Version 10). SPSS Inc., Chicago, Illinois.

Starman, T.W. and J.E. Faust. 1996. Banking on new baskets. Greenhouse Grower 14(3):86, 88, 93. Starman, T.W. and M.S. Williams. 2000. Growth retardants affect growth and flowering of Scaevola. HortScience 35:36-38.

Warncke, D. 1995. Recommended test procedures for greenhouse growth media. In: Recommended soil testing procedures for the northeastern United States. Chapter 11. N.E. Reg. Publ. 493, p. 76-82.

Warren, R.G. and B. Benzian. 1959. High levels of phosphorus and die-back in yellow lupins. Nature 184:1588.

Watanabe, F.S., W.L. Lindsay, and S.R. Olsen. 1965 Nutrient balance involving phosphorus, iron and zinc. Soil Sci. Soc. Amer. Proc. 29:562-565.

Whipker, B.E. and P.A. Hammer. 1994. Determination of injurious phosphorus levels in poinsettias. HortScience 29:85-87. 